\title{
Conflicting Judicial Views
}

\section{By Ora Wirliams}

Consideration and discussion of controversial questions before the judicial tribunals of the nation and the states are rarely made known to the public, except to the extent revealed through filing of dissenting opinions by members of the court. It goes without saying, however, that prolonged and even bitter arguments take place between members of the several courts, before whom causes are submitted, when opinions varying upon points of law are expressed and considered.

It is a departure from customary procedure when members of the judiciary engage in public discussion of the application of the law of the land, and most edifying to the average citizen when such discussion does occur.

Many years ago, back in 1898, to be exact, such a public discussion of opposing and conflicting views did take place. At a general meeting of Des Moines professional and business men, members of the Iowa supreme court then engaged in heated arguments almost to the point of becoming angered in exchanges of comment. It was at a monthly dinner of the old Grant club in Des Moines held May 19, 1898, that Chief Justice Horace E. Deemer gave a distinguished address defending use of the injunction by the courts.

Few men have stood higher upon the Iowa court through the years than Justice Deemer. There were times during his long service that it was characterized "a Deemer court." It was even said that some other members during that period would not announce their own ideas until Deemer had spoken, the implication being significant, whether true or not.

The formal address of Judge Deemer upon this occasion was on "The Courts the Safeguard of the Nation." It was ably written and well delivered. He gave the 
use of the injunction, for which the Federal judiciary had been so widely and severely criticized, his unqualified endorsement and going further, complained very seriously of the freedom of criticism to which the courts of the country are subjected by press and people. He gave expression to the sentiment that one of the functions of the government was to "protect the people against themselves."

At the conclusion of Deemer's remarks, Judge Waterman, also of the supreme bench, being called out to discuss the sentiments embodied in the address, took sharp issue with the speaker, and in the course of comment said that no man who could not stand criticism of his public acts, or believed himself above criticism, should aspire to the bench. He expressed the belief that adverse public sentiment often corrected the abuses of courts and exerted a healthy influence which restrained them from the commission of arbitrary acts.

\section{SAFETY For OuR Institutions}

Judge Deemer selected as the sentiment of his address, "Let us then begin by safeguarding against every enemy threatening the perpetuity of free republican institutions." He said that although General Grant had well earned the sobriquet of the "Silent Statesman," yet his words of warning uttered on a historic occasion were full of meaning and almost inspired by prophetic insight into the future. The nation had just awakened to a realization of the complete meaning of his words as they came to the nation from Mount McGregor, pointing out the necessity for a good navy and the imminent demand for sea coast defenses.

Breaking with the thread of his theme, which was indicative in the opening sentences of a survey of the dangers with which the nation is encompassed from without, the speaker utilized the opportunity to raise his voice against the dangers which he believed lurked within.

"Let us," he said, "begin by guarding ourselves 
against every enemy threatening perpetuity of free republican institutions. Disguise it as we may, the republic is in more danger from the vagaries of anarchists, communists and of socialists than from the fancies of the so-called modern economists.

"The insidious attacks of the new school of politicians upon the existing order of things, disguised though it may be in criticism of the decisions of the courts, is a menace to our social system, and if carried to its logical conclusion, means the destruction of one of the three co-ordinate branches of government and the establishment of a tribunal that shall know no law save the caprice of the time and the clamor of the mob. The man who affirms that the government is so powerful that it may make something out of nothing, and in the same breath asserts that it is unable to protect its citizens in the enjoyment of their property rights, is endowed with a mind capable of speculation along lines unhampered by sequence or syllogism. Of what use is it to create if you cannot protect?

"Modernisms and faulty social and economic theories may nearly all be traced to imperfect notions of the functions and uses of government. Thus, the recent calumniators of courts base their assaults upon false premises and immature ideas of the social compact. The courts as at present constituted are as much an outgrowth of the struggle of the individual for liberty as is a constitution, and he who would boldly destroy it is so far breaking with the past that he becomes a revolutionist, and not a reformer. Reduced to their last analysis, these onslaughts upon the courts are assaults upon our fundamental laws, and have for their ultimate end the establishment of a new social order. That many of their cohorts deny this conclusion is to me proof of infirmity of mind or of want of integrity of purpose.

Purpose of THE JudrCIARY

"The judicial department of government is organ- 
ized primarily for the purpose of giving to each and every one that to which he is of right entitled. Morality and law are not the same, and yet so it is that if men obey the dictates of their own conscience, they are generally in accord with the laws of their country. It may be safely affirmed that all law has an ethical basis, and except in so far as it may be controlled by arbitrary statutes is in strict accord with the general consensus of opinion as to what is right and just between man and man. We are all agreed as to what is meant by the words 'life and liberty' as used in the Declaration of Independence, and I think ought to be agreed as to what is meant by that other term, 'the pursuit of happiness.' It means the acquisition and retention of property, in which we are all engaged and for which we are all striving. Knowledge that what I earn and own is mine and will be protected by the strong arm of the law, is invaluable; and when Christian or socialist proposes to take it from me and confer it upon another, he is striking at the very root of progress and undermining the very corner of the republic.

"We are now met' with the charge that the courts have become the refuge of the rich and powerful, and a menace to the poor; that government of today is a government by injunction. If this indictment were true; if courts were unable to protect the weak from the strong; if justice had opened her eyes and held unbalanced scales; if judges had usurped the functions of the legislative or executive departments of the government, then indeed, would it be time to have another revolution and a new social compact. True, the relations of the judiciary are more complex and the problems with which it is confronted more intricate than when our forefathers so dearly purchased their liberty; but our sense of justice is just as acute and our ideas of fair play as intense as in the early days of the century. 


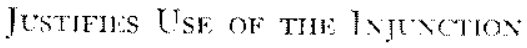

"The injunctions against which specife complaints are made have for their basis principles and rules as old as the common law itself. Courts have the undoubted right, and it is their duty to protect property in the possession of their officers. They also have the right to protect suitors from irreparable injury to property and from multiplicity of suits, and under any form of govermment they have the undoubted right to see that all national functions. such as the carriage of the mails and protection to interstate commerce, are preserved. Under the one or the other of the head: all the orders now complained of were issued. One order, I think. went so far as to compel employes in work arainst their will, but this was promptly discredited by the supreme court of the nation.

"This reversal again demonstrated that involuntary servitude will not be tolerated under our system of sovermment. Granted the right to issue its decrees protecting property and restraining interference with national functions, the courts have the undoubted right to enforce such orders. Without such right the law forum would be a mere debating society.

"But, it is said, a man has a right to a jury trial. What, a jury trial to determine whether ho will oby the order of the court? Nonsense. He who so argues appeals to the prejudice of his hearers. Courts have the risht to enforce their orders in such instances by imprisonment if necssary. Right here is the rub. as I see it. Jury trials during the sympathetic strike ir? Chicago would have been a farce. Property was being bumed and destruyed. The United States mails wore being stopped and interstate commerce was at a standstill. What would have been the result if the authorities had resorted to the usual process of arrest. indictment, trial, appeal? Rapine and murder would have done their worst, and treason and rebellion would have staked through the land. Many yet believe we weru on the verge of a rebellion at the time, and if it had 
not been for the cool head and deliberate fudrment if Judre Woods, the army of discontent would have organized a fored which would have proved a menace second only to the rebellion of 1061 .

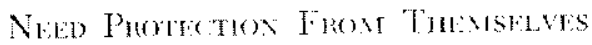

"But what are we offered in place of the existing systom? Boards. Buards of arbitation buarts of conciliation. These, if adupted, will, in my judsment. bo the first step towards socidisn. The socialint must, of necessity, first strike at that institution whith fosters liberty in its true sense and proteds propery. The anarchist is. as a rule, the socialist in action. Fe must first destroy existing forms in order that he may introduce his phalanxes; hence he attacks the courts. and having destroved them he would intruluce lis board, which knows no law and recosnizes no rule of human conduct save as may appear just to tho heated imarination of the moment. We sometimes fail to reconize that the suremment is orianized m the theory that the people must protect themselves from themselves. This is the sule iliat of writon constitutions.

"The remedy for our present isls, if any is nocded. is not to be found in arbitration, but in and through the law. To strike down tho court is rebelion: in amend the law or the constitution is an exercise of the hishest privilere of citizenship. If. then, there be grievances for which the law does not afford a remedy. relief is to be had through the lesislative departmetit. Statues ought to represent the well-settled othical ideas of the times, and legislator's should be actuatod by the highest and purest motives.

"Whon such laws are cnacted. courts are cur ready to lend their aid to the accomplishment of their ends. Except in rare instunces sovelnment by injunction has been a government of law and not of men, a govemment which has protected property and preserved life, a government which has saved us from anarchy and rebellion, a government in which law is 
supreme, a government which has protected with absolute impartiality every right recognized by law."

\section{Judge Waterman Takes Exceptions}

The sentiments were applauded, yet evidences were not wanting to suggest that there were those in the assemblage to whom the doctrine enunciated was unpalatable, and that they were not in accord with the ideas expressed. But none were quite prepared for the almost sensational denouement that ensued when Judge Waterman, the most recently elected of the associate judges to the supreme bench, responding to an invitation to discuss the paper read by his colleague, took pronounced and almost radical issue with the views of Judge Deemer on the use of the injunction, and mildly scouted the pessimistic alarms sounded by him concerning the dangers that lurked in socialism, anarchy and modern economic ideas.

"I have listened to the reading of the paper," said Judge Waterman, "and I am compelled to confess that in much it contained and in many of the sentiments uttered I do not agree with Judge Deemer. I do not believe that in a country where churches, school houses and colleges light every city and country with the lamp of Christianity and broad intelligence, there is much danger to be feared from anarchists or socialists.

"Again, in the resort of the courts upon almost every occasion to the use of the injunction, I cannot agree with Judge Deemer. It is an arbitrary power which I confess seems to have been exercised by some of the courts without the consideration being given it that should have been.

"I cannot place myself in accord with the position taken by my colleague with reference to criticism of the courts. I believe that if absolved from criticism and permitted to exercise authority without restraint the courts would not, sometimes, hesitate to go out and beyond the radius of their functions. Healthy criticism, in my opinion, is a good thing for the courts. 
It tends to keep them in touch and informed on the trend of public sentiment, which, after all, is the potent force which towers above all others in crystalizing good ideas into law. Judges, like others, are human, and subject to the weakness of the flesh. I believe that a judge in the trial of cases should consult his heart as well as his head. Both should be used in determining the issues.

"I do not apprehend there are today any more anarchists in proportion to population than there were 300 years ago. Government by injunction and its abuse is attested by the statement made by Judge Deemer that one of the orders issued by a federal judge during the Chicago strike was declared usurpation by the supreme court of the United States, and only demonstrates the lengths to which some judges would go if unrestrained by public opinion. The occasional protests from the public at apparent attempts of usurpation of authority by the judiciary exert a healthy influence upon the courts.

"Perhaps I should not have spoken as I have, and maybe it would have been better had I written out my remarks, but you asked me for an expression of opinion and I have given it to you. You have it. I thank you."

Judge Robinson, also present, followed and avoided exciting antagonisms by taking what he termed a "middle course," which provoked laughter, the intent being so evident as to be amusingly apparent. The discussion continued for nearly an hour, when the meeting adjourned.

\section{Whence Comes the Threat}

Democracy is threatened by the inertia of good people, by the selfishness of most people, and by the evil designs of a few people.-Stanley King. 
Copyright of Annals of Iowa is the property of State of Iowa, by \& through the State Historical Society of Iowa and its content may not be copied or emailed to multiple sites or posted to a listserv without the copyright holder's express written permission. However, users may print, download, or email articles for individual use. 